TIME AND DOSE DEPENDENT EFFECT OF SUCROSE AND LACTOSE INTAKE ON SUCRASE AND LACTASE ACTIVITIES IN 655 ADULT RAT JEJUNUM. Toshinao Goda, Sergio A. Busta-
mante, Otakar Koldovsky. University of Arizona College of Medimante, Otakar Koldovsy. To characterize mechanisms leading to a dietary evoked increase of sucrase (Sa) and lactase (La) activity by dietary intake of disaccharides [sucrose (S) or lactose (L)], two-monthold rats were fed for 7 days a low carbohydrate diet (LC) [BBA 676:108], then for the next 3 to 72 hours, they were force fed a $S$ or $\mathrm{L}$ diet ( 20 or $40 \mathrm{cal} \%$ ). Activity of La and Sa increased after 3 hours, but only Sa continued to increase for the next 48 hours. The effect of variation of carbohydrate intake on $\mathrm{Sa}$ and La after 12 hours is summarized below.

$\underline{\text { Diet }} \rightarrow \underline{L C}$

$$
20 \mathrm{cal} \frac{\text { Sucrose }}{40} \quad \underline{\mathrm{cal}} \%
$$

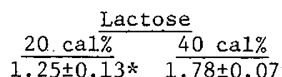

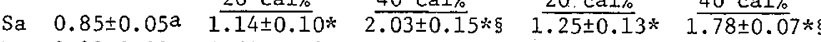
La $0.39 \pm 0.02 \quad 0.61 \pm 0.08 * 0.83 \pm 0.06 * 0.69 \pm 0.10 * 0.63 \pm 0.08 *$ a) Mean \pm SEM; mmole/hr/g prot. Significant effect: $*=$ LC v.s $S$ or $L ; \xi=20$ cal\% vs 40 cal\%. N (group): $4-7$.

Whereas Sa increased with greater intake of $S$ and $L$, La did not. Determination of changes of enzyme activity along the height of the villus-crypt columns showed that the increase of Sa began at the lower villus, but the increase of La occurred along the entire villus.

Conclusion. Differences in response of $\mathrm{Sa}$ and $\mathrm{La}$ to $\mathrm{S}$ and $\mathrm{L}$ intake (time, dose, locus) suggest that the increase of both disaccharidases evoked by dietary intake of $S$ or $L$ is the result of different mechanisms.
VITAMIN LEVELS IN INFANTS AND CHILDREN RECEIVING $\dagger 658$ PARENTERAL NUTRITION. Harry L. Greene, Mary E. Moore Murrell and Hamid Said. Vanderbilt Medical Center, OakTand Childrens, Baylor Medical College and University of Cajifornia, L.A. No studies have been done to evaluate AMA guidelines for Pediatric intravenous vitamins. Two age groups received the AMA suggested dosages as MVI Pediatric: 1) Infants less than $1500 \mathrm{gm}$ gested dosages as MVI Pediatric: 1) Infants less than $1500 \mathrm{gm}$
$(\mathrm{N}=21)$ $(N=21)$ for 3 wks (65\% of Pediatric dose) and 2) Term newb
to age 10 yrs $(N=24)$ for $<4$ wks and, $N=8$ for $3-6$ months $)$. Water soluble vitamin blood levels were normal $\left(B_{1}, B_{2}, B_{3}, B_{6}\right)$ or elevated (folate, $B_{12}$, pantothenate) in all patients. Lipid soluble vitamins $D$ and $E$ were maintained at normai levels $\left(15-39 \frac{\mathrm{ng} / \mathrm{mT}}{15}\right.$ and $0.25-1.3 \mathrm{mg} / \mathrm{dl}$ respectively) in all patients in group 2 for up to 6 months on TPN. Vitamin A levels were below the lower normal range $(20 \mathrm{mcg} / \mathrm{dl})$ for two patients in group 2 and $a 11$ but two infants in group 1. Infants receiving oral Vitamin $E$ in addition to MVI showed higher blood tocophero 7 levels than those not receiving oral tocopherol (wk $1=2.32 \pm 0.2$ vs $1.3 \pm 0.1 \mathrm{mg} / \mathrm{d} 1, \mathrm{p}<0.01$; wk $3=1.4 \pm 0.08$ vs $2.9 \pm 0.4, p>$ $0.01)$. Tests of Vitamin A demonstrated $\simeq 80 \%$ loss in TPN solutions exposed to light and intravenous tubing. This effect was reversed by infusing MVI in Intralipid.

Conclusion. With the exception of Vitamin A, AMA guidelines appear appropriate for infants and children receiving TFN. The low Vitamin A blood levels can be explained from losses from light exposure and adherence to plastic I.V. tubing, a phenomenon obviated by the addition of the vitamins to Intralipid. No oral Vitamin $E$ should be given with MVI Pediatric in TPN.

\section{$\dagger 656$}

ROLE OF PANCREATIC PROTEASE IN DEGRADATION PROCESS OF SUCRASE-ISOMALTASE IN RAT JEJUNUM. Toshinao Goda, of Medicine, Departments of Pediatrics and Physiology, Tucson.

Whereas sucrase activity is higher in the upper jejunum than in the lower jejunum, the activity of isomaltase is the same in both segments. To analyze the mechanism involved in this differ ence, the common pancreatico-biliary duct was occluded in 3-monthold rats. Control animals were sham operated. Eighteen hours after the operation, the activity of sucrase (SA) and isomaltase [determined as palatinose-hydrolyzing activity (PA)] and immunoreactive amount of sucrase-isomaltase (IRS) were determined in the upper (UJ) and the middle third (LJ) of jejunoileum. cacy of the duct ligation was verified by the determination of trypsin activity of each segment. The results (mean \pm SEM) are summarized below.

\begin{tabular}{|c|c|c|c|c|c|c|}
\hline Group & $\underline{\mathrm{N}}$ & 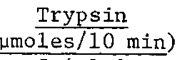 & $\frac{\mathrm{SA}}{\mu \mathrm{mol} / \mathrm{m}}$ & $\frac{\text { PA }}{\text { prot } / h \text { ) }}$ & SA/PA & ( $\mu \mathrm{mo} \frac{\text { IRS }}{1 / \mathrm{mg} \text { prot }}$ \\
\hline Sham & $3 \mathrm{UJ}$ & $5.4 \pm 1.2$ & $2.8 \pm 0.2$ & $0.62 \pm 0.05$ & $4.6 \pm 0.2$ & $18 \pm 2$ \\
\hline & LJ & $17.7 \pm 2.9 *$ & $2.0 \pm 0.3$ & $0.72 \pm 0.07$ & $2.8 \pm 0.4 *$ & $15 \pm 3$ \\
\hline Ligated & $5 \mathrm{UJ}$ & $2.0 \pm 0.4 \S$ & $3.5 \pm 0.4$ & $0.71 \pm 0.03$ & $4.8 \pm 0.4$ & $14 \pm 1$ \\
\hline & LJ & $3.9 \pm 0.6 * \S$ & $3.3 \pm 0.5$ & 03 & $.4 \S$ & $15 \pm 3$ \\
\hline
\end{tabular}
Significant differences: $* U J$ vs LJ; $\$$ sham vs ligated.

The decreased SA/PA ratio in LJ was restored by pancreatic duct ligation. Significant linear regression was established between trypsin activity in intestinal lumen and $\mathrm{SA} / \mathrm{PA}$ ratio $(\mathrm{r}=-0.801$, $\mathrm{N}=16, \mathrm{p}<0.001)$. Studies thus show that pancreatic proteases have more effect on the degradation of sucrase than on isomaltase.

EFFECTS OF' TPN ON INTESTINAL DEVELOPMENT

657 Robert M. Goldstein, David L. Dudgeon, Gordon L. Luk, Paul of Medicine, Johns Hopkins Hospital, Department of Surgery, Division of Pediatric Surgery, Baltimore, Maryland

Parenteral nutrition (TPN) is vital in the nutritional suppor of infants with surgical GI tract lesions. Rat studies demonstrate decreased small bowel(SB) mucosal enzymes and intestinal atrophy. We studied the effects of TPN during the phase of rapid intestinal growth and development in piglets. Groups of three 6 wk old weaned piglet littermates received for 3 wks an amino acid ( $8 \mathrm{gm} / \mathrm{kg} /$ day), glucose $(35 \mathrm{gm} / \mathrm{kg} /$ day), fat $(2.5 \mathrm{gm} / \mathrm{kg} /$ day $)$ solution intravenously (TPN) or by gastrostomy(GF) or were given chow at an equivalent caloric value. No differences were noted in avg weight gain $(13-15 \mathrm{gm} / \mathrm{kg} /$ day $)$, total serum protein $(4.5-4.8 \mathrm{gm} / \mathrm{al})$, BUN $(9-12 \mathrm{mg} / \mathrm{dl})$ and Hct $(30-358)$. Comparing the TPN and GF to the chow-fed animals, there were: 1) decreased growth of the stomach, SB and pancreas, 2) decreased SB mucosal disaccharidases. The TPN group compared to baseline measurements demonstrated 1) decreased SB weight and length, 2) decreased pancreatic weight. Histology of SB mucosa in TPN animals showed decreased mucosal depth, villous height, crypt depth and epithelial cell number to the mid-villous area. These findings suggest 1) stomach, SB and pancreatic growth are dependent on route of administration and composition of diet 2) SB mucosa and pancreas atrophy in young piglets maintained on TPN 3) intestinal disaccharidases are decreased in the proximal SB in piglets maintained on both intravenous and intragastric infusion of a TPN solution.
659 INORGANIC SULFATE IN PRETERM INFANTS FED HUMAN MILK FORTIFIED WITH Ca, P, AND BOVINE WHEY Prank R. Greer, Ann McCormick, Jeff Loker, (spon. by Richard D. Zachman) University of Wisconsin, Dept. of Pediatrics, Madison.

We hypothesized that fortifying mother's own mflk (MON) with bovine whey $(.85 \mathrm{~g} / \mathrm{dl})$, Ca $(90 \mathrm{mg} / \mathrm{dl})$, and $P(45 \mathrm{mg} / \mathrm{dl})$ would improve weight gain, increase bone mineral content (BMC photon absorptiometry) \& prevent $P$ deficiency syndrome ( hypophoton turia hypery) infants fed human alk. 35 pretern infanor (Bud infants fed human milk. 35 preterm infants (BWT $=1193+200 \mathrm{~g}, \mathrm{GA}=30$ $+1.7 \mathrm{wk})$ were placed on 1 of 4 feedings: $\operatorname{MOM}(\mathrm{n}=10)$, fortified MOM (PMOM, $n=10)$, Similac $20 \mathrm{cal}(\mathrm{SIM}, \mathrm{n}=9)$ similac Special Care 20cal (SSC, $n=6)$. Results \pm SD for 6 wks of full feedings :

wt gain $\mathrm{g} / \mathrm{kg} /$ day $\frac{\text { MOM }}{13+1} \quad \frac{\text { FMOM }}{17+3} \quad \frac{\text { SIM }}{14+3} \quad \frac{\text { SSC }}{16+2} \quad \frac{\text { ANOVA }}{\mathrm{p}<.01}$ $\begin{array}{llllll}\text { Protein intake } \mathrm{g} / \mathrm{kg} / \mathrm{d} & 3.1 \pm .7 & 3.8 \pm .4 & 2.4 \pm .3 & 2.7 \pm .4 & \mathrm{p}<.01\end{array}$ $\begin{array}{llllll}\mathrm{Ca} \text { intake } \mathrm{mg} / \mathrm{kg} / \mathrm{d} & 62 \pm 14 & 144 \pm 30 & 95 \pm 4 & 181 \pm 18 & \mathrm{p}<.01\end{array}$ $\begin{array}{llrccc}\mathrm{P} \text { intake } \mathrm{mg} / \mathrm{kg} / \mathrm{d} & 27 \pm 12 & 71 \pm 19 & 72 \pm 5 & 90 \pm 9 & \mathrm{p}<.01\end{array}$ $\begin{array}{llllll}\text { Urine TRP\% } & 99 \pm 0 & 98 \pm 1 & 72 \pm 8 & 93 \pm 6 & \mathrm{p}<.01\end{array}$ $\begin{array}{llllll}\text { Urine Ca mg/24hr } & 26 \pm 3 & 23 \pm 3 & 7 \pm 6 & 12 \pm 1 & \mathrm{p}<.01\end{array}$

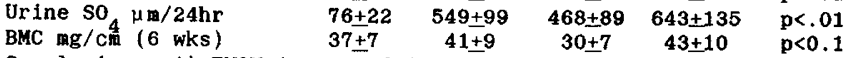
Conclusions: 1) FMOM increased in wt faster than MON. 2) Portfying MOM with $\mathrm{Ca} / \mathrm{P}$ dId not increase BMC or alter signs of $P$ deficiency. 3) Bovine whey (high in sulfur) increases urinary $\mathrm{SO}_{4}$. Thus for PMOM hypercalcuria despite adequate $P$ intake maybe due in part to increased protein (bovine whey) intake \& increased urinary $\mathrm{SO}_{4}$, as reported in adults.
SAFE ADMINISTRATION OF INTRALIPID DURING PHYSIOLOGIC 660 JAUNDICE IN SICK PRETRRM INPANTS. Gary R. Gutcher, of wisconsin, Dept of Pediatrics, Madison

In order to determine whether or not intravenous fat could be safely given to premature infants with respiratory disease during the first week of life. Intrallpid was infused for $18 / 24$ hours each day during days 2 through 7 of 1 ife at doses increasing fro 0.5 to $2.0 \mathrm{~g} / \mathrm{kg} / \mathrm{d}$ over that period. Prior to and 6 hours after each daily initiation of the infusion, serum bilirubin (total and direct), albumin (ALB), non-esterified free fatty acids (NERA), triglycerides (TG), apparent unbound bilirubin (AUBC), salicylat triglycerides (TG), apparent unbound bilirubin (AUBC), salicy
saturation index (SSI), and hematofluorimeter indices were saturation index (SSI), and hematofluorimeter indices were
measured. Indirect bilirubin (IBIL), IBIL/ALB and NBPA/ALB molar ratios were computed. 9 premature infants with ventilatordependent RDS have been studied thus far.

During the study, maximum levels obtained were: IBIL $11.3 \mathrm{mg} / \mathrm{dl}$, IBIL/ALB 0.6 , TG $234 \mathrm{mg} / \mathrm{dl}$, NEFA $0.6 \mathrm{mBq} / \mathrm{L}$, and NEFA/ALB 2.43. During the infusions there were statistically significant $(p<0.01)$ elevation in TG $(44+2.7$ to $102+6.4 \mathrm{mg} / \mathrm{dl})$, NEFA $(0.08+0.013$ to $0.22+0.025 \mathrm{mEq} / \mathrm{L})$, and NEPA/ALB $(0.26+0.046$ to $0.71+0.095)$. However, no measures of bilirubin binding changed significantly. At the same time, strong correlation was noted between hematofluorimeter measures and IBIL/ALB; none was noted with SSI or AUBC.

We conclude that IBIL/ALB <0.8: 1) one may safely administer intravenous fat as assessed by these measures of bilirubin albumin binding; 2) Hematof luorimeter neasures detect changing IBIL/ALB parameters, but SSI and AUBC do not. 